\title{
Global positioning systems indicate landscape preferences of cattle in the subtropical savannas
}

\author{
N. Tomkins ${ }^{\mathrm{A}, \mathrm{C}}$ and P. O’Reagain ${ }^{\mathrm{B}}$ \\ ${ }^{A}$ CSIRO Livestock Industries, JM Rendel Laboratory, Rockhampton, QId 4702, Australia. \\ ${ }^{B}$ Queensland Department of Primary Industries and Fisheries, PO Box 976, Charters Towers, Qld 4820, Australia. \\ ${ }^{\mathrm{C} C o r r e s p o n d i n g ~ a u t h o r . ~ E m a i l: ~ n i g e l . t o m k i n s @ c s i r o . a u ~}$
}

\begin{abstract}
Large paddocks, a heterogeneous landscape and widely dispersed water points provide challenges for the sustainable grazing management of northern Australian beef properties. Determining grazing animal distribution and relating this to features in the landscape, including artificial water points, can assist in the sustainable management of these environments. This case study describes the distribution and landscape association of cattle for part of a single wet season. Twelve Brahman cows were fitted with global positioning system (GPS) collars for 8 weeks in a 1530 ha paddock that contained a diversity of land-types and a single artificial water point. Grazing preferences were initially limited to a 250-ha cleared area of clay soil sown with Cenchrus ciliaris. Thereafter, animals moved on to less fertile outlying areas of Eucalyptus and Acacia agyrodendron native pasture woodland. Mean convex polygon, the smallest polygon that contained $90 \%$ of positional data, increased from $229 \pm 37.6$ ha to $449 \pm 80.3$ ha over the first 3 weeks of the study. Animals avoided areas dominated by steep terrain and the preference index (proportion of GPS locations that occurred in a land-type divided by its relative cover) was less than unity for $71 \%$ of the paddock area. Although the performance of the GPS units was disappointing, the study verifies that GPS telemetry and satellite imagery can be used to quantify cattle distribution and probable grazing preferences in the extensive, spatially heterogeneous paddocks of northern Australia.
\end{abstract}

Additional keywords: grazing distribution, satellite imagery, sustainability, telemetry, preference index.

\section{Introduction}

The extensive grazing lands of northern Australia are spatially heterogeneous in both the quality and productivity of forage. The large size of many commercial paddocks (>1000 ha) and the limited number of artificial and natural water points also lead to an uneven pattern of grazing. This results in major challenges for sustainable land management. The ability to predict how cattle will respond to spatial variability in forage and water supply and to understand how land-types and geographical features modify these preferences are crucial to developing sustainable grazing strategies for these extensive environments (Turner et al. 2000; O'Reagain 2001; Bailey 2005).

At the landscape scale, the location of water has been identified as a primary determinant of grazing distribution in large paddocks (Ganskopp 2001). Cattle may travel 2 to $10 \mathrm{~km}$ per day from water (Hodder and Low 1978; Ganskopp 2001) and grazing distribution is centred on a single water point. Overgrazing often occurs and a piosphere develops (Lange 1969). The positioning of water is therefore effective in manipulating cattle distribution in large, semi-arid pastures (Ganskopp 2001).

Grazing animals typically select areas offering the greatest intake rate of digestible energy and crude protein (Pinchak et al. 1991) and avoid areas far from water and/or dominated by unpalatable forage species. Landscape use is therefore determined by the quality and availability of forage, conditional upon the animal's metabolic requirements and other factors such as accessibility, predation risk and protection from the elements (O'Reagain and Schwartz 1995). The foraging strategies used by the animal determine the intensity, timing and spatial location of plant defoliation and consequently the grazing impact on the pasture.

Preference for a specific land-type by free-ranging cattle can result in over-grazing, localised soil erosion and loss of biodiversity. There may also be an overall reduction in carrying capacity as the selected areas in a paddock are often the most productive. In time, over-grazed areas become less attractive to livestock and the cycle of over-grazing is repeated elsewhere, resulting in loss of landscape integrity and eventual paddockscale degradation (Mott 1987).

Understanding of the main factors driving spatial selection by livestock in northern Australia is limited; dependent on prediction of relatively coarse, broad-scale patterns of utilisation (O'Reagain and Schwartz 1995). Indirect methods of measuring selection, such as estimating pasture utilisation, are labour intensive (Roth et al. 2003) as are direct animal observations. However, direct observations have provided comprehensive data on the grazing behaviour of cattle and the distribution of activity in large paddocks have been determined for central Australia (Low et al. 1981a; Pickup 1994). Such 
comprehensive behavioural data cannot be captured by using global positioning system (GPS) devices alone. However, combining GPS positional data (which can be determined almost continuously) with geographic information systems (GIS) and spatially explicit population dynamic models is becoming more common in developing sustainable land management strategies. Stochastic modelling of grazing behaviour within spatially heterogenous landscapes is also emerging as an important tool for understanding grazing systems (Wade et al. 1998; Parsons et al. 2001), but sufficiently large datasets on the grazing behaviour and distribution are needed.

The objectives of this case study were to highlight how GPS collars could be used to (i) identify the pattern of landtype selection of free-ranging cattle in a large (>1000 ha) heterogeneous paddock and (ii) identify the major edaphic and environmental factors relevant to landscape selection in the subtropical savannas.

\section{Methods}

Study area

The study was conducted on Trafalgar Station $\left(20^{\circ} 30^{\prime} \mathrm{S}\right.$, $\left.145^{\circ} 58^{\prime} \mathrm{E}\right) 60 \mathrm{~km}$ south-west of Charters Towers, Queensland, Australia, between November 2005 and January 2006. The longterm (90 year) mean annual rainfall for the site is $650 \mathrm{~mm}$, concentrated in the summer months. The study site was a 1530 ha paddock that had not been grazed since the previous growing season in April 2005. It contained a diverse mixture of landtypes (Table 1) and a single artificial water point in the extreme south-west corner (Fig. 1). Paddock surveys and Landsat satellite imagery were used to map the dominant vegetation types. Pasture yield was determined in January 2006 by the BOTANAL method (Tothill et al. 1992) along six transects, each 3 to $4 \mathrm{~km}$ long, which bisected all vegetation types. Operators visually assessed pasture biomass in $2 \times 2 \mathrm{~m}$ quadrats at $50 \mathrm{~m}$ intervals. Yield, expressed as total standing dry matter (TSDM, kg/ha), was calculated for each of the five main soil types identified at the study site.

\section{Animal distribution}

Twelve 3-4-year-old Brahman cows (with calves) were randomly selected from a breeding herd of 183 cows during a routine muster in November 2005. Each animal was fitted with a GPS unit (L400, BlueSky Telemetry Ltd, Scotland), mounted on a collar. The units archived GPS positional data at userdetermined intervals, together with the date, time, number of satellites, operating temperature and operational status (Table 2). Animal activity could not be measured directly. The units were programmed to obtain a position (from at least four satellites) every $30 \mathrm{~min}$. Collars were removed from the animals in January 2006, after 56 days.

The fix rate (two positions per hour) used in this study was chosen to maximise the number of positions collected for each animal, given the expected life of the batteries. Increasing the fix rate increases the resolution of positional data collected and therefore better reflects true animal movement, but reduces the effective period of deployment. A lower GPS fix rate (one position per $\mathrm{h}$ ) would extend the duration of a deployment because the rate of power consumption is reduced. However, calculating the total distance travelled by an animal, based on the sum of straight-line paths between successive GPS positions would be less accurate and the result an underestimate.

\section{Analysis of GPS tracking data}

The distance travelled by an animal in an hour was defined as the sum of the straight-line distances between three successive GPS locations. This value was calculated for each hour of the day and for each animal. The distances between the single water point and each GPS position were calculated and these values averaged over the study period for each animal. The range from water (the maximum distance from the water point reached by an animal over the study period) was calculated. Standard errors of these variables (distance travelled per hour, average distance from water and range from water) were based on the number of animals in the analysis. Spatial Analyst tools in ArcMap9.1 (ESRI, Australia) were used to calculate the mean convex polygon values $(\mathrm{MCP}$; the smallest polygon which contained

Table 1. Main land-types and associated vegetation, Trafalgar Station, Queensland, Australia

\begin{tabular}{|c|c|c|}
\hline $\mathrm{No}^{\mathrm{A}}$ & Name & Description \\
\hline 1 & Cleared pastures & $\begin{array}{l}\text { Cleared blackwood (Acacia agyrodendron) woodland on heavy clays and duplex soils. Over-sown with Cenchrus } \\
\text { ciliaris (buffel grass), but having good native pastures in good condition in small areas. Some bare patches } \\
\text { also present }\end{array}$ \\
\hline 2 & Blackwood woodland & $\begin{array}{l}\text { Intact blackwood woodland on heavy clays and texture contrast soils; some on stony shallow soils. Sparse, but } \\
\text { palatable native grasses }\end{array}$ \\
\hline 3 & Box woodland & $\begin{array}{l}\text { Open box (Eucalyptus brownii) woodland on texture contrast soils, with narrow-leafed ironbark (Eucalyptus } \\
\text { crebra) in places; better native grasses such as desert bluegrass (Bothriochloa ewartiana) in more productive } \\
\text { patches }\end{array}$ \\
\hline 4 & Silver-leafed ironbark & $\begin{array}{l}\text { Silver-leafed ironbark (Eucalyptus melanophloia) with wattle (Acacia spp.) and some E. crebra on shallow, } \\
\text { texture-contrast soils. Very sparse native grasses. Substantial areas of bare ground }\end{array}$ \\
\hline 5 & Narrow-leafed ironbark & E. crebra on better red soils. Severe scalding in places, sparse native grasses \\
\hline 6 & Shallow stony slopes & $\begin{array}{l}\text { Silver-leafed ironbark (Eucalyptus shirleyi) with some lancewood (Acacia shirleyi) and wattle thickets, on stony } \\
\text { shallow soils. Very sparse wanderrie (Eriachne spp.) grasses in thicker scrub, spinifex (Triodia spp.) tussocks, } \\
\text { with E. crebra on very stony open slopes }\end{array}$ \\
\hline 7 & Water point & Fenced area $<1$ ha freely accessible to stock \\
\hline
\end{tabular}

${ }^{\mathrm{A}}$ Refer to Fig. 1. 


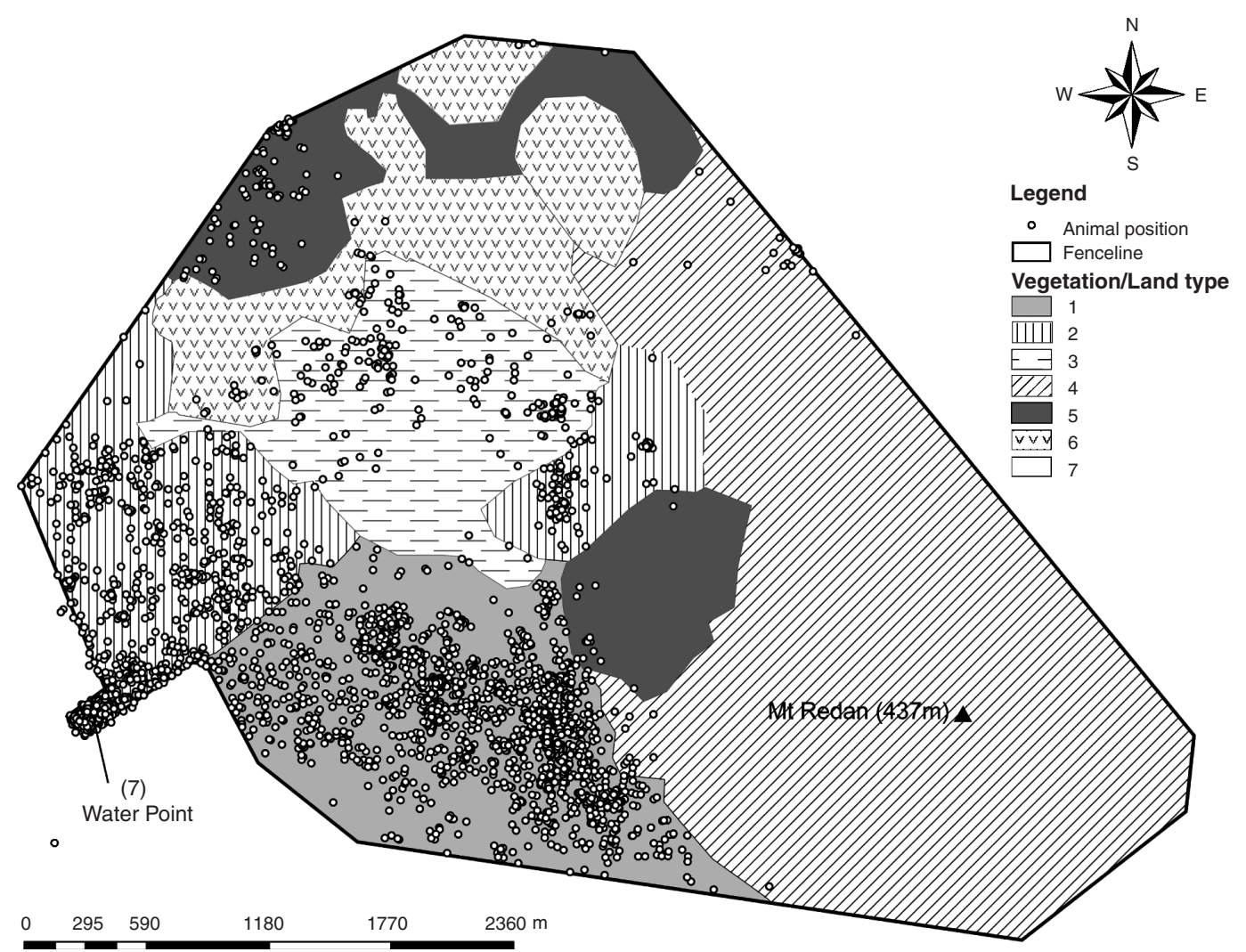

Fig. 1. The grazing distribution of Brahman cows $(n=7)$, each fitted with a GPS collar for 8 weeks, Trafalgar Station, Queensland, Australia. Numbers in legend indicate different land-types based on soil and dominant vegetation as described in Table 1.

Table 2. Data fields recorded by BlueSky ${ }^{\mathrm{TM}}$ Telemetry GPS collars

\begin{tabular}{ll}
\hline Output & Description \\
\hline Time: date & h/min/sec : day/month/year \\
Status & $\begin{array}{l}\text { Success in locating a fix dependent on number of satellites available; } \text { OK if location is determined, } \text { no position data if }<4 \text { satellites } \\
\text { are found in the allocated search period or GPS receiver fault if unit fails to operate }\end{array}$ \\
$\begin{array}{l}\text { Longitude/latitude } \\
\text { Decimal degrees }\end{array}$ \\
$\begin{array}{l}\text { Vertizontal error; } \\
\text { m. Horizontal dilution of precision (HDOP) and Vertical dilution of precision (VDOP) calculated by the GPS unit based on satellite } \\
\text { geometry }\end{array}$ \\
$\begin{array}{ll}\text { Sat. number } & \text { m. Calculated using HDOP, VDOP with a Karman filter } \\
\text { Temperature } & \text { Absolute number of satellites available to obtain a two-dimensional location }\end{array}$ \\
\hline
\end{tabular}

$90 \%$ of positional data) and animal distribution according to land-type.

Preference and standardised indices were calculated for each land-type (Hobbs and Bowden 1982). The preference index was the proportion of GPS positions for individual animals in a land-type divided by the proportional area of that land-type available. Preference for a land-type is indicated by a value $>1$, while a value $<1$ indicates that animals used a land-type less than in proportion to its available area (Bowyer and Bleich 1984). A standardised selection index (Chesson's index) was calculated as the proportion of preference for that land-type (including association with the water point) divided by the sum of preference indices for all land-types (Chesson 1978).

\section{Results and discussion}

\section{GPS unit performance}

GPS performance in this study was marginal, with only 7 of the 12 units providing sufficient data for spatial analysis of animal distribution. Continuous positional data was obtained for up to 44 days. Only the first three weeks of positional data could be used to make valid comparisons, using MCP values based on data collected from three animals. Problems with variable success in obtaining a GPS position from at least four satellites and battery failures were identified. In addition, maximum daily air temperatures $>36^{\circ} \mathrm{C}$, combined with previous use of standard alkaline batteries, had resulted in internal corrosion of the 


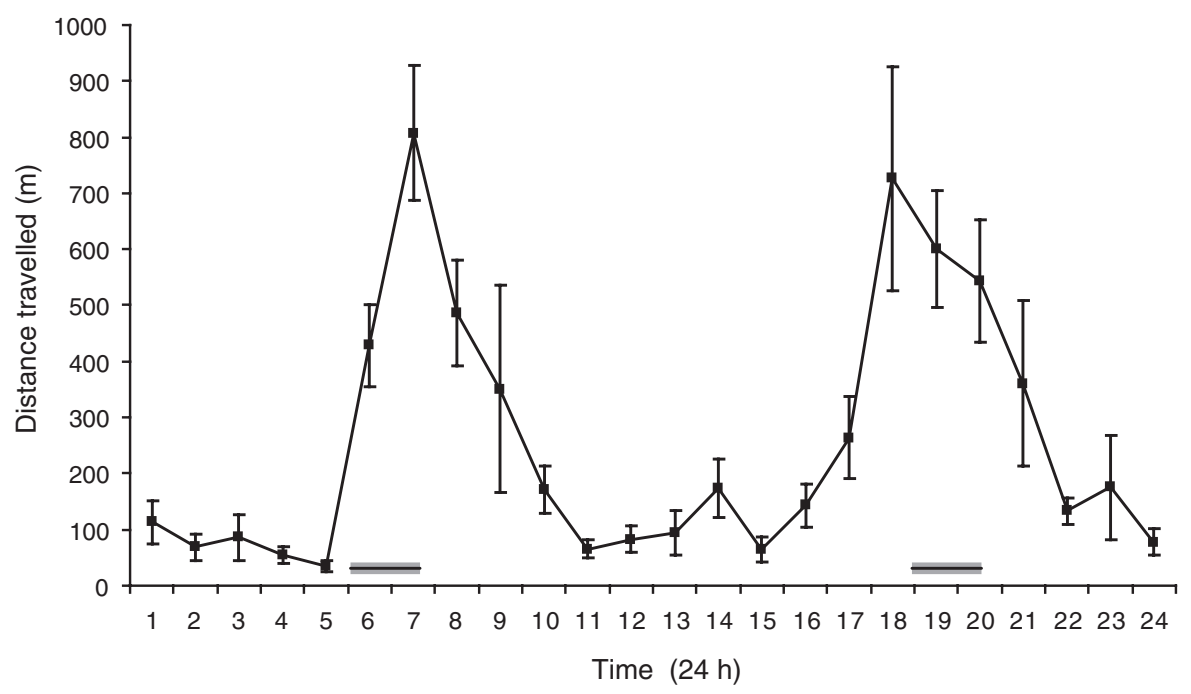

Fig. 2. The diurnal pattern of the mean ( \pm s.e.m.) distance travelled per hour by Brahman cows $(n=7)$ fitted with GPS collars, based on GPS positional data collected every $30 \mathrm{~min}$, Trafalgar Station, Queensland, Australia. The grey bars indicate approximate sunrise and sunset.

units. Although each unit was disassembled, decontaminated and tested before this study, residual corrosion of the circuit board was identified as the cause of poor functioning. Five of the 12 GPS units were affected to such an extent that data were collected intermittently or could not be retrieved. For this reason, the results presented here should be treated with caution, as they represent a small sample of the herd.

The number of locations that can be archived is generally dependent on the tracking schedule, configuration of satellites and their visibility to the GPS antenna. Cloud, dense canopy cover, and poor power supply to the GPS units would also contribute to inconsistent performance, but these were not the principal causes of the poor performance observed here.

\section{Rainfall and pasture yields}

Total annual rainfall for the 2005 calendar year at the study site was $619 \mathrm{~mm}$, slightly below the long-term average. Precipitation in the months before the study was below average, with no rainfall recorded in September and November. Scattered falls during the study period (total $121 \mathrm{~mm}$ ) ensured good growth of buffel grass (Cenchrus ciliaris) pastures on texture contrast and clay soils. Temperatures were generally hot (up to $3^{\circ} \mathrm{C}$ above average) during the study period, with maximum daily temperatures $>36^{\circ} \mathrm{C}$ common.

Pasture yield, in late January 2006 for each of the five major soil types, was estimated to be $1040 \mathrm{~kg} /$ ha for cleared pastures and blackwood woodland on heavy clay soils (Table 1, land-types 1 \& 2); $904 \mathrm{~kg} / \mathrm{ha}$ for box woodland on texture contrast soils (land-type 3); $595 \mathrm{~kg} /$ ha for silver-leafed iron bark on yellow earths (land-type 4); $956 \mathrm{~kg} /$ ha for narrow-leafed ironbark on red earths (land-type 5); and $519 \mathrm{~kg} /$ ha for stony shallow slopes (land-type 6).

\section{Animal activity}

A pronounced bimodality was observed in the daily pattern of movement by the collared animals. Activity peaked during the
Table 3. Distance travelled per day, average distance, range $^{A}$ and return distance from a single water point for Brahman cows fitted with GPS collars, Trafalgar Station, Queensland, Australia

\begin{tabular}{lcrr}
\hline & Mean \pm s.e.m. & Minimum & Maximum \\
\hline Distance travelled $(\mathrm{m} / 24 \mathrm{~h})$ & $8127 \pm 267$ & 3648 & 14698 \\
Distance from water $(\mathrm{m})$ & $1311 \pm 52.5$ & 30 & 2271 \\
Range $^{\mathrm{A}}$ from water $(\mathrm{m})$ & $3043 \pm 288$ & 2289 & 4125 \\
Distance travelled between $_{\quad} \quad 13811 \pm 4770$ & 5186 & 26670 \\
$\quad$ & & & \\
\hline
\end{tabular}

${ }^{\mathrm{A}}$ Maximum calculated distance from water $(n=7)$.

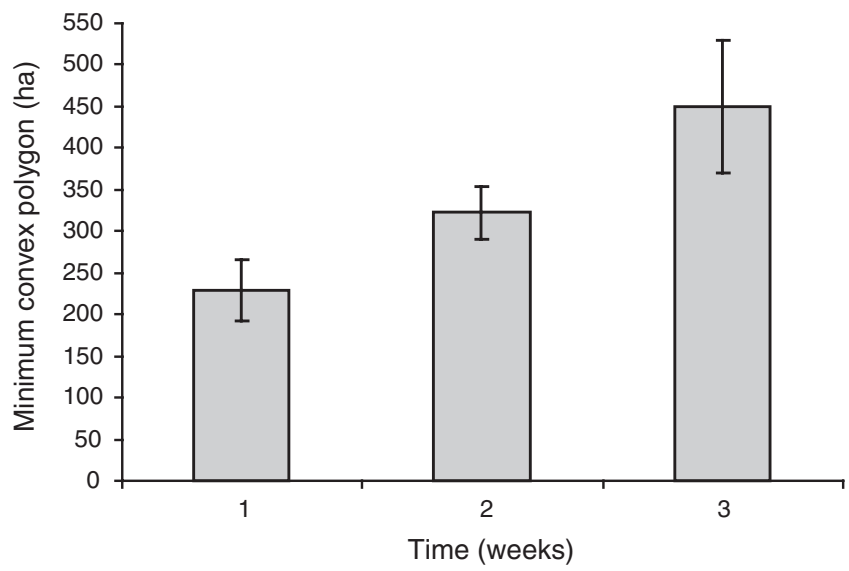

Fig. 3. Mean ( \pm s.e.m.) $90 \%$ minimum convex polygon values for the first three weeks of the study period for Brahman cows $(n=3)$ fitted with GPS collars, Trafalgar Station, Queensland, Australia.

early morning and evenings (Fig. 2), which were probably the main grazing times (Low et al. 1981a). Based solely on proximity to the artificial water point, cattle drank at dawn and dusk. Some animals did not return to the water point for up 
Table 4. Available proportions, used proportions, forage ratios and the probability of selection for different land-types based on soil/vegetation classes for Brahman cows, Trafalgar Station, Queensland, Australia

\begin{tabular}{lcccc}
\hline & $\begin{array}{c}\text { Available } \\
\text { proportion }^{\mathrm{A}}\end{array}$ & $\begin{array}{c}\text { Used } \\
\text { proportion }^{\mathrm{B}}\end{array}$ & $\begin{array}{c}\text { Preference } \\
\operatorname{index}^{\mathrm{C}}\left(w_{\mathrm{i}}\right)\end{array}$ & $\begin{array}{c}\text { Standardised } \\
\operatorname{index}^{\mathrm{D}}\left(B_{\mathrm{i}}\right)\end{array}$ \\
\hline $\begin{array}{l}\text { Water point } \\
\text { Land-type }\end{array}$ & 0.002 & 0.17 & 85.0 & 0.94 \\
$\quad$ 1. Cleared pastures & 0.16 & 0.55 & 3.4 & 0.04 \\
2. Blackwood woodland & 0.13 & 0.18 & 1.4 & 0.02 \\
3. Box woodland & 0.11 & 0.05 & 0.45 & $<0.01$ \\
4. Silver-leaf ironbark & 0.38 & 0.01 & 0.03 & $<0.01$ \\
5. Narrow-leaf ironbark & 0.11 & 0.03 & 0.27 & $<0.01$ \\
6. Shallow, stony slopes & 0.11 & 0.01 & 0.09 & $<0.01$ \\
\hline
\end{tabular}

${ }^{\text {A }}$ Size of land-type/total size of study area.

${ }^{\mathrm{B}}$ Count of animal locations per land-type/total count.

${ }^{\text {C }}$ Proportion used/proportion available land-types (Hobbs and Bowden 1982).

${ }^{\mathrm{D}}$ Chesson's index (Chesson 1978).

to 3 days, but they presumably were utilising small ephemeral waterholes during this time. There was considerable variation between cows in distances travelled over $24 \mathrm{~h}$ and between apparent drinking events (Table 3 ), although mature cows with calves generally travel less than yearling cattle or non-lactating females (Arnold and Dudzinski 1978).

During the first 3 weeks of the study, MCP increased from $229 \pm 37.6$ ha to $449 \pm 80.2$ ha (Fig. 3). Spatial analysis of the data indicated that the initial MCP was centred on the relatively flat, cleared 250 ha of buffel grass pasture (Table 1, landtype 1) that was also within $4.1 \mathrm{~km}$ of water (Fig. 1). Similar grazing distances from water have been reported in other studies (Hart et al. 1993; Hodder and Low 1978). Thereafter, animals began to use adjoining, uncleared Acacia agyrodendron native pasture woodlands and less fertile, outlying areas of Eucalyptus woodland (Fig. 1). Selection indices based on all GPS positional data confirmed the grazing preference for buffel grass pastures on heavy clay and texture contrast soils (Table 4). This was expected as the buffel grass pasture responded quickly to the rainfall that fell during the study period with new growth of highquality forage. As grazing continued, MCP increased from 15 to $29 \%$ of the study area. For this calculation, only a small number of animals $(n=3)$ with uninterrupted positional data could be used. The results should be treated with caution, as they could be influenced by idiosyncrasies of individual animals rather than showing a general trend for the herd as a whole. Regular visual observations would have provided a more detailed dataset on animal behaviour, but preferences indices for land-types or different plant communities cannot be reliably determined because of the bias in selecting cattle in open communities for observations (Low et al. 1981a, 1981b).

Animals also clearly avoided a large area of steep, stony terrain in the north-east of the study site. Positional data indicated that $49 \%$ of the paddock had a preference index $<0.25$ (Table 4) indicating that a large proportion of the paddock was seldomly used. This included areas dominated by scattered Eucalyptus shirleyi, dense lancewood (Acacia shirleyi) and coarse unpalatable grasses such as wanderrie (Eriachne spp.) and spinifex (Triodia spp.). Apart from the sparse, low-quality forage growing on these slopes, the steep, stony terrain may have also been a physical barrier to accessing other areas on the extreme north-east side of the paddock. Consequently, collared animals were not found in over half the paddock and their activity was concentrated in areas close to water (Table 3 ), and presumably grazing in areas offering the greatest intake rate of high-quality forage. Cleared areas were grazed before less-preferred pasture types. For this study site, the estimated paddock carrying capacity would have to be strongly discounted for the non-preferred land-types to avoid over-grazing of the more productive and accessible areas relatively close to the single artificial water point.

\section{Conclusion}

The reliance on detailed visual observations to determine grazing patterns has now been replaced with the commercial development of GPS devices for livestock. Grazing distributions, associations with land-type and the potential impacts on the pasture resource can now be quantified for extensive properties. This study has demonstrated that grazing distribution at the study site was determined by the location of water, pasture quality and terrain, confirming observations made in other studies (Low et al. 1981a; Pinchak et al. 1991; Hunt et al. 2006). Interpretation of similar datasets that also use GPS to quantify grazing animal distribution (Hunt et al. 2006) and the insight to the behaviour and behavioural mechanisms of individual animals that it provides, will further contribute to the understanding of observed grazing patterns across northern Australia. Landcare and community-based natural resource management groups are now able to direct funding to support the establishment of additional water points and fencing, primarily to manage grazing of sensitive areas and riparian zones. Studies in extensive paddocks with GPS-collared animals will be important in quantifying the impact of these measures in obtaining even grazing distribution and therefore sustainable use of large, spatially heterogeneous paddocks.

\section{Acknowledgements}

We are grateful to the Landsberg family of Trafalgar Station for their generous help and support in the conduct of this study. Sam Williams, Chris Holloway, John Bushell and Peter Allen provided valuable assistance. 
Ed Charmley, two anonymous reviewers and Vivienne Mawson commented usefully on the manuscript. The project was partly funded by Meat and Livestock Australia.

\section{References}

Arnold, G., and Dudzinski, M. (1978). 'Ethology of free-ranging domestic animals.' (Elsevier Scientific Publishing: New York.)

Bailey, D. (2005). Identification and creation of optimum habitat conditions for livestock. Rangeland Ecology and Management 58, 109-118. doi: 10.2111/03-147.1

Bowyer, R. T., and Bleich, V. C. (1984). Effects of cattle grazing on selected habitats of southern mule deer. California Fish and Game 70, 240-270.

Chesson, J. (1978). Measuring preference in selective predation. Ecology 59, 211-215. doi: 10.2307/1936364

Ganskopp, D. (2001). Manipulating cattle distribution with salt and water in large arid-land pastures: a GPS/GIS assessment. Applied Animal Behaviour Science 73, 251-262. doi: 10.1016/S0168-1591(01)00148-4

Hart, R., Bissio, J., Samuel, M., and Waggoner, J. (1993). Grazing systems, pasture size and cattle grazing behaviour, distribution and gains. Journal of Range Management 46, 81-87.

Hobbs, N. T., and Bowden, D. C. (1982). Confidence intervals on food preference indices. The Journal of Wildlife Management 46, 505-507. doi: $10.2307 / 3808667$

Hodder, R., and Low, W. (1978). Grazing distribution of free-ranging cattle at three sites in the Alice Springs district, central Australia. Australian Rangeland Journal 1, 95-105. doi: 10.1071/RJ9780095

Hunt, L. P., Petty, S. R., Cowley, R., Fisher, A., MacDonald, N., and Ash, A. (2006). Options for improving grazing distribution in savanna rangelands. In: "The cutting edge. Conference Papers of the 14th Biennial Conference, Australian Rangeland Society'. Renmark, SA. (Ed. P. Erkelenz.) pp. 225-228. (Australian Rangeland Society: Northam.)

Lange, R. (1969). The piosphere: sheep track and dung patterns. Journal of Range Management 22, 396-401.

Low, W. A., Tweedie, R. L., Edwards, C. B., Hodder, R. M., Malafant, K. W., and Cunningham, R. B. (1981a). The influence of environment on daily maintenance behaviour of free-ranging shorthorn cows in central Australia. I. General introduction and descriptive analysis of daylong activities. Applied Animal Ethology 7, 11-26. doi: 10.1016/03043762(81)90048-1

Low, W. A., Tweedie, R. L., Edwards, C. B., Hodder, R. M., Malafant, K. W., and Cunningham, R. B. (1981b). The influence of environment on daily maintenance behaviour of free-ranging shorthorn cows in central Australia. II. Multivariate analysis of duration and incidence of activities. Applied Animal Ethology 7, 27-38. doi: 10.1016/0304-3762 (81)90049-3
Mott, J. J. (1987). Patch grazing and degradation in the native pastures of the tropical savannas in northern-Australia. In: 'Grazing-lands research at the plant-animal interface'. (Eds F. Horn, J. Hodgson, J. Mott and R. Brougham.) pp. 153-161. (Winrock International: Morrilton, AR.)

O'Reagain, P. J., and Schwartz, J. (1995). Dietary selection and foraging strategies of animals on rangelands. Coping with spatial and temporal variability. In: 'Recent developments in the nutrition of herbivores. Proceedings of the IV International Symposium on the Nutrition of Herbivores'. Clermont-Ferrand, France. (Eds M. Journet, E. Grenet, M.-H. Farce, M. Theriez and C. Demarquilly.) pp. 407-423. (INRA: Paris.)

O'Reagain, P. J. (2001). Foraging strategies on rangelands: effects on intake and animal performance. In: 'Grassland ecosystems: an outlook into the 21st century. Proceedings of the XIX International Grassland Congress'. Sao Pedro, Brazil. (Eds J. A. Gomide, W. R. S. Mattos and S. C. da Silva.) pp. 277-284. (Brazilian Society of Animal Production: Sao Paulo.)

Parsons, D. J., Armstrong, A. C., Turnpenny, J. R., Matthews, A. M., Cooper, K., and Clark, J. A. (2001). Integrated models of livestock systems for climate change studies. 1. Grazing systems. Global Change Biology 7, 93-112. doi: 10.1046/j.1365-2486.2001.00392.x

Pickup, G. (1994). Modelling patterns of defoliation by grazing animals in rangelands. Journal of Applied Ecology 31, 231-246. doi: $10.2307 / 2404539$

Pinchak, W. E., Smith, M. A., Hart, R. H., and Waggoner, J. W. (1991). Beef cattle distribution patterns on foothill range. Journal of Range Management 44, 267-275.

Roth, C. H., Prosser, I. P., Post, D. A., Gross, J. E., and Webb, M. J. (2003). 'Reducing sediment export from the Burdekin catchment.' CSIRO Land and Water, Meat and Livestock Australia Final Report - NAP3.224. (Meat and Livestock Australia: North Sydney.)

Tothill, J., Hargreaves, J., Jones, R., and McDonald, C. (1992). BOTANAL - a comprehensive sampling and computing procedure for estimating pasture yield and composition. 1. Field sampling. Technical Memorandum No. 78, CSIRO.

Turner, L. W., Udal, M. C., Larson, B. T., and Shearer, S. A. (2000). Monitoring cattle behaviour and pasture use with GPS and GIS. Canadian Journal of Animal Science 80, 405-413.

Wade, T. G., Schultz, B. W., Wickham, J. D., and Bradford, D. F. (1998). Modelling the potential spatial distribution of beef cattle grazing using a Geographic Information System. Journal of Arid Environments 38, 325-334. doi: 10.1006/jare.1997.0333

Manuscript received 13 November 2006; accepted 2 October 2007 